\title{
Partykuły epistemiczne w Rocznikach Jana Długosza*
}

\author{
Epistemic Particles in the Annals of Jan Długosz
}

\begin{abstract}
This article discusses the use of epistemic particles in Jan Długosz's Annals, a work considered the greatest achievement of Polish medieval historiography written in Latin. The analysis focuses on particles in the quantitative and distributional aspects. The semantics of these particles, their role in the narrative of the Annals, their syntan (in particular their relationship with hosting utterances), as well as their position in the linear order of the sentence are discussed in detail. This study has shown that Długosz's use of these particles does not differ greatly from the norms of classical Latin. In the introductory section of the article, the author presents research on Latin and Polish particles, using the latter in an examination of Latin examples. The author's treatment of this subject is indebted to the terminological and methodological strategies developed by Maciej Grochowski, which are given here extensive application.
\end{abstract}

Key words: particles, epistemic modality, Medieval Latin, Jan Długosz, Annals

\begin{abstract}
Abstrakt: Autor artykułu omawia użycie partykuł epistemicznych w Rocznikach Jana Długosza. Analizie zostały poddane zagadnienia ich dystrybucji w kronice oraz wzorców w obrębie literatury łacińskiej, z których Długosz mógł korzystać, wprowadzając partykuły do narracji. Uwagę poświęcono również zasięgowi oddziaływania partykuł epistemicznych $w$ funkcji operatora modalnego oraz kwestii położenia tych leksemów w linearnym szyku zdania. Przeprowadzone analizy pokazują, że sposób użycia partykuł przez Długosza nie odbiega znacząco od normy językowej utrwalonej w łacinie klasycznej. Zasadniczy wywód został poprzedzony wstępem teoretycznym na temat badań nad partykułami w języku łacińskim i - ze względów metodologicznych i porównawczych - w języku polskim. W artykule wykorzystywane są bowiem propozycje terminologiczne i interpretacyjne wypracowane dla współczesnej polszczyzny przez Macieja Grochowskiego.
\end{abstract}

Słowa kluczowe: partykuły, modalność epistemiczna, łacina średniowieczna, Jan Długosz, Roczniki

\section{Wprowadzenie}

Partykułom $w$ języku łacińskim poświęcono do tej pory kilka wnikliwszych opracowań bazujących na korpusach łaciny klasycznej i późnoantycznej (np. Kroon, 1995; 2011; Rosén, 2009; SCHRICKx, 2011; PInKSTER, 2015). Brakuje natomiast badań, w których uwzględniano by materiał językowy łaciny średniowiecznej. Ponieważ $w$ gramatyce łaciny

* Publikacja finansowana $w$ ramach programu Ministra Nauki i Szkolnictwa Wyższego pod nazwą "Narodowy Program Rozwoju Humanistyki” w latach 2018-2022, nr projektu 0444/NPRH5/ H30/84/2017 (Długosz 2.0. Elektroniczny korpus i narzędzia analizy języka Jana Długosza). 
średniowiecznej występowały pewne zjawiska odbiegające od normy łaciny starożytnej (np. Weyssenhoff-Brożkowa, 1998; Dinkova-Bruun, 2011), zakres użycia partykuł $w$ łacinie średniowiecznej z całą pewnością zasługuje na bliższą uwagę i analizę ich potencjalnych przemian. Niniejszy artykuł stanowi próbę omówienia tego zagadnienia na przykładzie Roczników Jana Długosza (1415-1480), najważniejszego dzieła historiograficznego polskiego średniowiecza, które ze względu na swoje rozmiary, jak również kunszt literacki autora, stwarza możliwość przeprowadzenia badań na w miarę obszernym i do tego dopracowanym pod względem językowym materiale.

Analizie podlegają w szczególności cechy pragmatyczne i syntaktyczne partykuł epistemicznych, w niniejszym artykule określanych niekiedy z uwagi na swoją podstawową funkcję także partykułowymi operatorami modalnymi (za: WolanıN, 2012: 524). Mają one ogromne znaczenie dla wyrażania modalności epistemicznej $w$ dziele polskiego historyka. Do tej grupy należą leksemy takie, jak certe ‘na pewno', forsan 'może', forsitan 'być może', sane 'bez wątpienia', profecto 'z pewnością’ itp. W pierwszej części artykułu przedstawione zostaną założenia teoretyczne i stan badań nad partykułami w języku łacińskim, zułaszcza partykułami epistemicznymi. Znajdą się tam również wybrane zagadnienia z badań nad partykułami $w$ języku polskim, które wykorzystuję przede wszystkim $w$ celu udoskonalenia metodologii pracy. W części drugiej będą omówione kryteria wyboru materiału badawczego. W trzeciej i czwartej - analizie zostaną poddane: dystrybucja badanych leksemów w korpusie, zasięg ich oddziaływania (czyli wyrażenia, z jakimi współwystępują i jakie komentują) oraz pozycja $w$ linearnym szyku wypowiedzi. Prezentowane tutaj wyniki zostaną przeze mnie uwzględnione $w$ pracy doktorskiej poświęconej partykułowym operatorom modalnym w Rocznikach Jana Długosza, która powstaje w ramach projektu „Długosz 2.0. Korpus i narzędzia analizy języka". W pracy tej wykorzystuję tekst nowego wydania Roczników (Annales [AnN.]) oraz ich polski przekład autorstwa Julii Mrukównej (RoczNIKı [Rocz.]), podobnie więc postępuję tutaj.

\section{Partykuły a modalność epistemiczna}

Na wstępie warto przynajmniej przybliżyć zagadnienie modalności epistemicznej, której „podstawowym leksykalnym wykładnikiem” są właśnie partykuły (Wolanin, 2012: 524). Jest to typ modalności intencjonalnej deklaratywnej, a więc służącej do informowania odbiorcy o określonym stanie rzeczy. Modalność epistemiczną można podzielić na asertoryczną (nienacechowaną) i nieasertoryczną (nacechowaną). Pierwsza z nich jest środkiem wyrażania konstatacji (asercji), czyli informacji pewnych (obiektywnie prawdziwych) ze stanowiska nadawcy. Jest ona sygnalizowana za pomocą trybu oznajmującego czasownika i nie wymaga użycia dodatkowych wykładników. Druga - modalność nieasertoryczna - wyraża subiektywne przekonanie nadawcy o prawdziwości danej informacji. Stan przekonaniowy nadawcy może mieć przy tym różne odcienie: wątpliwości, niepewności, możliwości, prawdopodobieństwa czy konieczności (GrzegorczyKowa, 2010: 150-156; Wolanin, 2012: 516-519).

Do wyrażania nieasertorycznej modalności epistemicznej $w$ języku łacińskim służą środki morfologiczne, takie jak tryb coniunctivus oraz czas futurum, środki leksykalne, takie jak partykuły, czasowniki epistemiczne i modalne oraz niektóre wyrażenia przyimkowe, a także 
środki syntaktyczne, takie jak konstrukcja nominativus cum infinitivo, niektóre wyrażenia przymiotnikowe i przysłówkowe, wyrażenia o charakterze parentetycznym oraz interrogatywa (por. WolAnin, 2012: 524-542).

Partykuły epistemiczne $w$ języku łacińskim $w$ tradycyjnym opisie gramatycznym były często utożsamiane z przysłówkami'. Badacze anglosascy określają je wraz z zaprzeczeniami i spójnikami terminem particles (partykuły), przyjmując jako wspólną ich cechę nieodmienność (np. Allen, Greenough, 2006: 126-130). Tradycja niemiecka umieszcza część badanych leksemów w klasie przysłówków (np. Hoffman, Szantyr, 1972: 333-335), a część wplata między innymi do grupy adversative Partikeln (partykuły przeciwstawienia) (np. Hoffman, SzAntyr, 1972: 492-493), nie uwidaczniając jednak ich modalizującego znaczenia. Przez gramatyków francuskich partykuły epistemiczne są na ogół określane jako adverbes (przysłówki) (np. BORTOLussı, 2000: 79, 264). W opisie polskim wreszcie pojęcie partykuły nie występuje w ogóle (przed: Wolanin, 2012), a badane leksemy są definiowane jako przysłówki (np. WIKARJAK, 2019 [1978]: 48-49).

W duchu prac anglojęzycznych do kwestii partykuł epistemicznych podszedł również Harm PINKSTER (2015), przedstawiciel szkoły funkcjonalnej gramatyki dyskursu (Functional Discourse Grammar). Przypisuje je bowiem do klasy przysłówków, nie określa ich jednak wbrew tradycjom anglosaskiej filologii klasycznej - zbiorczym terminem particles. W stanowiącej podsumowanie jego wieloletnich badań nad łacińską gramatyką monografii The Orford Latin Syntan umieszcza je w obrębie grupy satellites (satelity), podzielonej ze względu na ich związek z wypowiedzią i funkcję na dwie dalsze grupy - intradyktalne adjuncts (okoliczniki) oraz ekstradyktalne disjuncts (modalizatory). Te ostatnie odnoszą się w jego ujęciu do całej wypowiedzi oraz do nastawienia i stanowiska nadawcy (PInKSTER, 2015: 923-932)². Właśnie do tej grupy zaliczają się badane w tym artykule leksemy. Chociaż $w$ sensie klasy gramatycznej dalej są one przez niego traktowane jako przysłówki, to $w$ sensie klasy funkcjonalnej stanowią już część szerszej grupy satelitów. Dla mnie natomiast szczególnie istotne znaczenie ma tutaj wyraźne podkreślenie funkcji modalizującej partykuł epistemicznych.

Założenia funkcjonalnej gramatyki dyskursu stanowiły również podstawę badań, które przeprowadziła Hannah Rosén (2009). Dokonała ona dokładnej analizy korpusu łaciny starożytnej, na którego podstawie wyłoniła dziesiątki leksemów organizujących koherencję i kohezję wypowiedzi oraz wyrażających nastawienie nadawcy. Rosén określiła je zbiorczym terminem particles (partykuły), (w celu odróżnienia od przysłówków), dzieląc je na cztery podgrupy $w$ zależności od ich funkcji ${ }^{3}$ :

1) connective particles/connectors (partykułowe operatory spójności);

2) discourse markers (partykułowe operatory dyskursu);

3) modalizers (partykułowe operatory modalne);

4) focus markers (partykułowe operatory fokalne).

1 Podobnie bywa zresztą $w$ innych językach, por. RAmAT, RıcCA, 1998. Literatura dotycząca tego problemu w samym tylko języku polskim jest obszerna, por. SGPP: 22-25.

2 Szerzej o przyjętym rozumieniu intradyktalności i ekstradyktalności por. Wolanin, 2012: 517-519, 524-526.

${ }^{3}$ W nawiasach podaję przyjęte przeze mnie polskie odpowiedniki tych terminów. Wzoruję je na określeniu „partykułowe operatory modalne”, stosowanym w pracy Wolanina (2012). 
Badaczka opisała całą ich klasę, opatrując ją kategoriami tożsamymi z ograniczeniami przypisywanymi polskim partykułom (por. SGPP: 26). W takim ujęciu partykuły nie mogą być konstytuentami zdania, nie stanowią członów grup syntaktycznych, nie należą do otwartej klasy i nie są autosemantyczne. Ponadto Rosén zauważyła, że wspomniane uprzednio podgrupy mogą się przenikać, a leksemy do nich należące mogą pełnić kilka różnych funkcji (np. być zarówno operatorem modalnym, jak i operatorem spójności; Rosén, 2009: 327). W przypadku partykułowych operatorów modalnych badaczka zwróciła szczególną uwagę na ich funkcje, pewne podobieństwa $w$ ich użyciu do parentetycznych użyć czasowników epistemicznych oraz na współwystępowanie partykuł i wykrzyknień w bezpośrednim sąsiedztwie (Rosén, 2009: 321-322). Podążając właśnie za jej interpretacją, dokonałem wyboru materiału badawczego.

Zauważenie odrębności klas gramatycznych oraz funkcji partykuł i przysłówków ma znaczenie fundamentalne, ponieważ umożliwia dokładniejsze ich opisanie na zasadzie kontrastu. Podobna dychotomia występuje również $w$ języku polskim, prowadząc niekiedy do

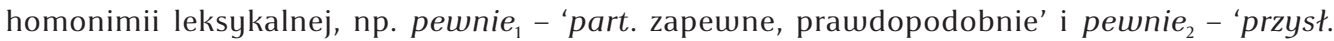
z pewnością siebie, bez wątpliwości’: „Pewnie ${ }_{1}$ pilot przed wylądowaniem nie czuje się zbyt pewnie ${ }_{2}$ (SGPP: 23). Związana z ewolucją niektórych przysłówków w partykuły oraz wzajemnym przenikaniem się obu klas w perspektywie synchronicznej (por. Rosén, 2009: 374-378; Kleszczowa, 2015: 37-64) homonimia jest być może oczywista, ale wyraźne zwrócenie uwagi na opisane zjawisko motywuje do zachowania ostrożności podczas analizy semantycznej i funkcjonalnej badanych leksemów. Jak bowiem wykażę w dalszej części artykułu, homonimiczne jednostki występują również w Rocznikach Długosza.

W nurcie gramatyki funkcjonalnej została napisana także praca Josine ScHRICKx (2011), w której poprzez analizę wybranych partykuł zostały pogłębione badania Rosén. Wprawdzie w tytule swojej monografii Schrickr używa terminu Modalpartikeln (partykuły modalne), ale $w$ toku analizy badane jednostki przypisuje do klasy Satzadverbien (przysłówki zdaniowe). Badane leksemy określa również, ze względu na ich funkcję, terminem 'Commitment'Marker (znaczniki zaangażowania) (SснRıскx, 2011: 23-24). Autorka skupia się na opisie znaczenia, funkcji i motywacji pragmatycznej leksemów nempe 'zaiste', quippe 'naturalnie', scilicet 'oczywiście', videlicet 'najwidoczniej' i nimirum 'bez wątpienia', ale zbiorczo podsumowuje również inne partykuły (głównie epistemiczne) i ich cechy (SCHRIckx, 2011: 211-260). To czyni jej pracę przydatną dla prowadzonej tutaj analizy.

Badania Rosén nad partykułami służącymi do wyrażania nacechowanej modalności epistemicznej wykorzystuje także Hubert Wolanın (2012: 121-123, 504-507, 524-526). Nie poświęca on temu zagadnieniu dużo miejsca, skupiając się jedynie na ogólnym przedstawieniu problemu i wykładników modalności. Jednakże, nawet jeśli zakres omówionych przez niego leksemów jest dość ograniczony, jego Gramatyka... przynosi wiele cennych obserwacji natury metodologicznej oraz terminologicznej. Zostaje w niej między innymi wprowadzony termin partykułowy operator modalny (WoLANIN, 2012: 524), którym posługuję się w moich badaniach.

Ze względów metodologicznych sięgam również po prace poświęcone partykułom $w$ języku polskim, przede wszystkim po model opisu zaproponowany przez Macieja Grochowskiego i jego zespół w Słowniku gniazdowym partykuł polskich (SGPP: 32-41). Model ten po pewnych modyfikacjach z powodzeniem może zostać zaadaptowany na potrzeby badań 
nad językiem łacińskim. W SGPP dokonano analizy partykuł polegającej na podziale ich na supergniazda, które z kolei dzielą się na gniazda. Omawiane tutaj leksemy należą do supergniazda partykuł epistemicznych, z którego $w$ niniejszym artykule wykorzystano dwa przypisane mu gniazda, korespondujące wyraźnie, jak się wydaje, z badanym materiałem, mianowicie niewykluczające oraz pewnościowe.

Pierwsze gniazdo obejmuje partykuły, które wskazują, że nadawca nie wyklucza prawdziwości pewnych wydarzeń i zjawisk, prezentuje je jako możliwe. Jego opis zawiera się w stwierdzeniu „możliwe, że nie R”, gdzie R - remat (SGPP: 61-67). Drugie gniazdo obejmuje partykuły, które wyrażają pewność nadawcy co do prawdziwości konkretnych wydarzeń i zjawisk, prezentują jego silne przekonanie o niej. Opis zawiera się tutaj w stwierdzeniu „wykluczam, że może nie być R”, gdzie R - remat (SGPP: 68-79). Poza adaptacją podziału na gniazda $w$ moich badaniach sięgam po między innymi opis zakresu użycia (funkcji) partykuł i ich szyku czy wskazanie możliwego występowania jednostek homonimicznych (SGPP: 37-41).

Trzeba oczywiście odnotować, że supergniazdo partykuł epistemicznych $w$ języku polskim obejmuje jeszcze kilka innych gniazd, między innymi hipotetyczne, inferencyjne czy wykluczające (SGPP: 45-114). Dokonany przeze mnie wybór partykuł epistemicznych, szczegółowo wyjaśniony $w$ następnej części opracowania, nie mieści się $w$ obrębie tych gniazd. Nie odrzucam oczywiście możliwości, że także dla języka łacińskiego można wskazać leksemy będące odpowiednikami polskich partykuł należących do wskazanych grup, nie są one jednak obecnie przedmiotem mojego zainteresowania.

Podczas analizy tylko dwóch, do tego przeciwstawnych sobie, grup partykuł kuszące jest powtórzenie uproszczenia, którego dokonała w swojej pracy Krystyna Kleszczowa (2015: 29) - podziału partykuł epistemicznych jedynie na gniazda pewnościowe i hipotetyczne. Chcąc jednak na tym etapie badań zachować wierność terminologii wykorzystywanej $w$ SGPP oraz nie wykluczając istnienia $w$ języku łacińskim odpowiedników partykuł epistemicznych $z$ innych gniazd, będę $w$ niniejszym artykule konsekwentnie stosował określenia „pewnościowe” i „niewykluczające”. Chętnie sięgam jednak po inne ustalenia Kleszczowej, między innymi te dotyczące kształtu partykuł czy kwestii wzajemnych relacji partykuł i przysłówków (KLeszczowa, 2015: 30-34, 37-64).

\section{Roczniki a partykuły epistemiczne}

Zanim omówię kryteria wyboru materiału badawczego, chciałbym przedstawić kilka zasadniczych dla niniejszego artykułu informacji dotyczących Roczników Jana Długosza. Są one uznawane za największe dzieło historiograficzne polskiego średniowiecza. Zostały napisane $w$ języku łacińskim $w$ drugiej połowie XV wieku, w latach 1455-1480. Przedstawiają historię Polski i jej sąsiadów, począwszy od czasów legendarnych (przed chrztem Polski $w$ roku 966) aż do ostatnich chwil życia autora. Składają się z dwunastu obszernych ksiąg - pierwszych dziesięć opisuje wydarzenia dawniejsze, do roku 1406, z kolei dwie ostatnie przedstawiają wydarzenia bliższe czasom historyka i jego otoczenia. Warto zaznaczyć, że objętość części „historycznej” i współczesnej Roczników jest nieomal taka sama. 
Charakterystyczną cechą dzieła Długosza jest pewna niejednorodność stylistyczna, która wynika zapewne z długiego procesu powstawania Roczników i wykorzystania w nich przez autora szerokiego spektrum źródeł. Ogromną część dzieła stanowią mniej lub bardziej przetworzone cytaty z tekstów historycznych (kronik, roczników itp.) oraz utworów literackich autorów różnych epok (GAWLAS, 1983: 7-16), znajduje się tam również dużo przepisanych in extenso źródeł dokumentalnych (NALEWAJEK, 2006: 26). Długosz nieustannie starał się ujednolicać i wygładzać styl swojego dzieła, o czym świadczy tzw. autograf Roczników (BCzart, rkps 1306) - kodeks rękopiśmienny autorstwa historyka i jego współpracowników z tekstem pierwszych dziesięciu ksiąg, dzięki któremu można prześledzić proces nawarstwiania się kolejnych redakcji kroniki. Podstawowy tekst kronikarz uzupełniał o nowe treści, a gdy przestawały się one mieścić na oryginalnej karcie, cała partia była usuwana, przepisywana na czysto i umieszczana we właściwym miejscu w kodeksie (NowakowsKı, 2012: 20-25). W ten sposób ogromne dzieło Długosza podlegało ciągłym modyfikacjom i doskonaleniu.

W obliczu bogactwa i różnorodności podań źródłowych kronikarz wielokrotnie stawał przed koniecznością zajęcia osobistego stanowiska odnośnie do prawdziwości i wiarygodności przedstawianych wydarzeń. W takich miejscach szczególnie uwidacznia się nieasertoryczna, czyli nacechowana, modalność epistemiczna. Do jej wyrażania służyły kronikarzowi różne środki morfologiczne, leksykalne i syntaktyczne, między innymi - uważane przez Wolanina za podstawowy jej wykładnik - partykułowe operatory modalne.

Przedmiotem przedstawianej tu analizy będzie jedenaście partykuł epistemicznych: forsan, forsitan, fortasse, forte, certe, nempe, nimirum, plane, profecto, sane, utique, które $w$ korpusie występują łącznie 124 razy. Ich zbiorcze zestawienie znajduje się w tabeli 1.

Tabela 1

Partykuły epistemiczne występujące w Rocznikach

\begin{tabular}{|c|c|c|c|c|c|c|c|c|c|c|c|}
\hline Szczegóły & \multicolumn{4}{|c|}{ Gniazdo niewykluczające } & \multicolumn{7}{|c|}{ Gniazdo pewnościowe } \\
\hline Partykuła & forsan & forsitan & fortasse & forte & certe & nempe & nimirum & plane & profecto & sane & utique \\
\hline Znaczenie & \multicolumn{4}{|c|}{$\begin{array}{l}\text { wyrażają niepewność nadawcy } \\
\text { („możliwe, że nie R”): } \\
\text { 'być może, chyba' }\end{array}$} & \multicolumn{7}{|c|}{$\begin{array}{l}\text { wyrażają pewność nadawcy („wykluczam, że może } \\
\text { nie być } R^{\prime} \text { ): 'bez wątpienia, z pewnością, na pewno' }\end{array}$} \\
\hline $\begin{array}{c}\text { Liczba } \\
\text { wystąpień }\end{array}$ & 7 & 15 & 2 & 25 & 16 & 5 & 10 & 3 & 22 & 15 & 4 \\
\hline Razem & \multicolumn{4}{|c|}{49} & \multicolumn{7}{|c|}{75} \\
\hline
\end{tabular}

Do wyboru materiału badawczego zostałem zainspirowany badaniami Rosén, prowadzonymi na korpusie łaciny klasycznej (z wieloma odniesieniami do łaciny archaicznej, Rosén, 2009: 350-351). Z wyłonionej przez nią grupy leksemów wybrałem te, których obecność udało mi się podczas kwerendy korpusowej potwierdzić w Rocznikach oraz które prymarnie są związane z modalnością epistemiczną. Ze względu na te kryteria została odrzucona między innymi partykuła quidem 'wprawdzie, zapewne', której podstawową funkcję należałoby określić jako fokalną ${ }^{4}$. Wątpliwości może budzić pominięcie tutaj party-

${ }^{4} \mathrm{~W}$ tym miejscu warto zwrócić uwagę na fakt, że w podobny sposób mogłaby zostać potraktowana partykuła utique, która ma szczególnie silny potencjał fokalny i może być zinterpretowana jako partykuła wyróżniająca ze znaczeniem ‘w szczególności, zwłaszcza' (por. Rosén, 2009: 376). Wydaje 
kuł certo 'pewnie', scilicet 'oczywiście', videlicet 'najwidoczniej' oraz vero 'zaprawdę'. Analiza ich wystąpień nie pozwoliła jednak na zakwalifikowanie ich do materiału badawczego, ponieważ certo używane było przez Długosza wyłącznie jako przysłówek, z kolei scilicet, videlicet i vero pełniły $w$ jego dziele wyłącznie funkcję organizującą spójność lub dyskurs wypowiedzi.

Ograniczenie materiału badawczego do miejsc, w których występują leksemy z przygotowanej listy, powoduje, że analiza nie obejmuje wielu innych jednostek leksykalnych, na przykład przysłówków odnoszących się do prawdziwości wypowiedzi: clare 'jasno', recte 'słusznie', vere 'prawdziwie', czy określonych wyrażeń przyimkowych lub przysłówkowych: procul dubio 'bez wątpienia', non dubie 'niewątpliwie'. Wprawdzie są one bardzo wyraźnie powiązane z modalnością epistemiczną (por. MAGNI, 2010: 210-211; SCHRICKX, 2013: 227; PINKSTER, 2015: 923-932), ale wprowadzenie ich na listę partykułowych operatorów modalnych wymagałoby przeprowadzenia stosownych badań na większym korpusie i przyjęcia dodatkowych założeń teoretycznych, między innymi rewizji ich klasy gramatycznej oraz zakresu pełnionych funkcji. $Z$ tego powodu nie będą one podlegać analizie $w$ niniejszym opracowaniu ${ }^{5}$.

W tym miejscu należy poczynić jeszcze istotne zastrzeżenie natury metodologicznej przedstawiona uprzednio specyfika Roczników nakazuje ostrożność w wyrokowaniu, czy określone partie tekstu są rzeczywiście autorstwa Długosza. W związku z tym należy w podobnie ostrożny sposób podchodzić do kwestii autorstwa poszczególnych zdań i, konsekwentnie, każdego wystąpienia partykuł epistemicznych. Musimy bowiem mieć zawsze na uwadze to, że Długosz mógł je przepisać, być może nawet dość mechanicznie, ze źródła, z którego korzystał $w$ danej partii tekstu.

Spośród 124 wystąpień partykuł epistemicznych w Rocznikach aż 36 zaczerpniętych jest ze źródeł dokumentalnych lub literackich - niemal 1/3 materiału badawczego nie pochodzi więc (bezpośrednio) od Długosza i występuje w kronice jedynie ze względu na obecność w przytaczanym przez niego tekście źródłowym. Może to rodzić wątpliwości, czy takie wystąpienia partykuł (zwłaszcza w wypadku źródeł dokumentalnych) powinny być tutaj brane pod uwagę. Za włączeniem ich do materiału badawczego może jednak przemawiać przesłanka dotycząca wykorzystywania i przytaczania w Rocznikach dokumentów sformułowana przez Agnieszkę Nalewajek. Jej zdaniem dokumenty służyły „uwiarygodnieniu, spragmatyzowaniu oraz urozmaiceniu opisu polskich dziejów. Obecność świadectw dokumentowych wprowadzała $w$ problematykę opisywaną przez dziejopisa autentyzm i wrażenie wielkiego znaczenia przedstawianych zagadnień" (NALEWAJEK, 2006: 108-109). Sięgnięcie po źródła dokumentowe było więc świadomym zabiegiem historyka, dlatego żadna z partykuł epistemicznych występujących pierwotnie w dokumentach czy źródłach historycznych i literackich nie została przeze mnie wyłączona z dalszych badań. Wprawdzie w wypadku niektórych partykuł kwestia pochodzenia z obcego dzieła będzie miała istotne znaczenie dla analizy, jednak wówczas będzie to w niniejszym opracowaniu sygnalizowane.

się jednak, że w wypadku Roczników na pierwszy plan wysuwa się raczej jej charakter epistemiczny i dlatego właśnie znalazła się ona w moim wyborze materiału badawczego.

${ }^{5}$ Wyrażenia przyimkowe mogą należeć do klasy partykuł czy też pełnić ich funkcję - dzieje się tak m.in. w języku polskim, np. współczesne bez wątpienia (SGPP: 27-32) czy historyczne bez pochyby, krom pochyby (KLEszczowA, 2015: 102-103). 


\section{Analiza kwantytatywna}

Właściwą analizę materiału badawczego należy rozpocząć od ustalenia liczby i przeglądu dystrybucji partykuł epistemicznych w Rocznikach. Tabela 1 pozwala zauważyć dominację partykuł pewnościowych nad niewykluczającymi, zarówno jeśli chodzi o liczbę leksemów (7:4), jak i liczbę ich wystąpień w obrębie każdego z gniazd (75:49). Widać dzięki temu wyraźną predylekcję autora do wzmacniania asercji swoich wypowiedzi i tym samym wpływania na przekonanie odbiorcy o ich prawdziwości - oczywiście niekoniecznie rzeczywistej (por. Kleszczowa, 2015: 28-29).

Dokładny wgląd $w$ tabelę pozwala również zauważyć, że niektórych partykuł Długosz używa częściej niż innych - do tej grupy należą forsitan, forte, certe, nimirum, profecto oraz sane. Świadczy to przede wszystkim o preferencjach leksykalnych autora, pozwala jednak również wyciągnąć wnioski dotyczące cech jego idiolektu. Istnieje bowiem warta rozważenia możliwość - zgodna z przyjętym założeniem o niejednorodnym charakterze autorstwa Roczników - że wyrazy rzadko używane przez historyka były przez niego przejmowane wraz z fragmentami źródeł historycznych lub literackich i nie należały do podstawowego zasobu jego słownika mentalnego.

Potencjalnie do takiej grupy może należeć występujące w Rocznikach tylko dwukrotnie fortasse. Pojawia się ono raz $\mathrm{w}$ przytoczonym in extenso liście Jana Paleologa (ANN. XIIa 303), z kolei jego drugie wystąpienie - unikatowe autorskie - może finalnie okazać się kryptocytatem. Nie da się jednak tego rozstrzygnąć bez dokładnych badań porównawczych i stylometrycznych nad dziełem Długosza ${ }^{6}$.

Ważną i związaną z przedstawionymi rozważaniami kwestię na płaszczyźnie leksykalnej stanowi wspomniane we Wprowadzeniu współistnienie homonimicznych $w$ stosunku do partykuł przysłówków. W Rocznikach takie „pary homonimiczne” występują w przypadku leksemów: certe 'part. na pewno' oraz 'przyst. pewnie' (2 razy), forte 'part. może' oraz 'przysł. przypadkiem' (9 razy), plane 'part. z pewnością' oraz 'przysł. wyraźnie' (3 razy), sane 'part. bez wątpienia' oraz 'przysł. właściwie' (1 raz). Także tutaj można zastanawiać się nad związkiem pomiędzy częstotliwością użycia danego leksemu a jego przynależnością do idiolektu autora. Dla ilustracji, przysłówkowe użycia certe pochodzą z listu księcia Mediolanu (AnN. XIla 294) oraz kryptocytatu z Epistolae sine nomine Francesca Petrarki (AnN. XIc 113). Użyte zaś aż 16 razy partykułowe certe (13 razy w wypowiedziach autorstwa Długosza) może świadczyć o tym, że w świadomości językowej autora leksem certe był nierozerwalnie związany z wyrażaniem pewności i prawdziwości sądów, a nie z opisem sposobu i okoliczności wykonywania danej czynności.

Dla badań nad modalnością epistemiczną w Rocznikach istotną kwestią będzie również dystrybucja partykuł epistemicznych na przestrzeni całego dzieła. Prezentuje ją wykres 1:

${ }^{6}$ Postulat takich badań wybrzmiał wyraźnie wśród badaczy w jubileuszowym Roku Jana Długosza 2015, por. Rajfura, 2018: 198-199. 


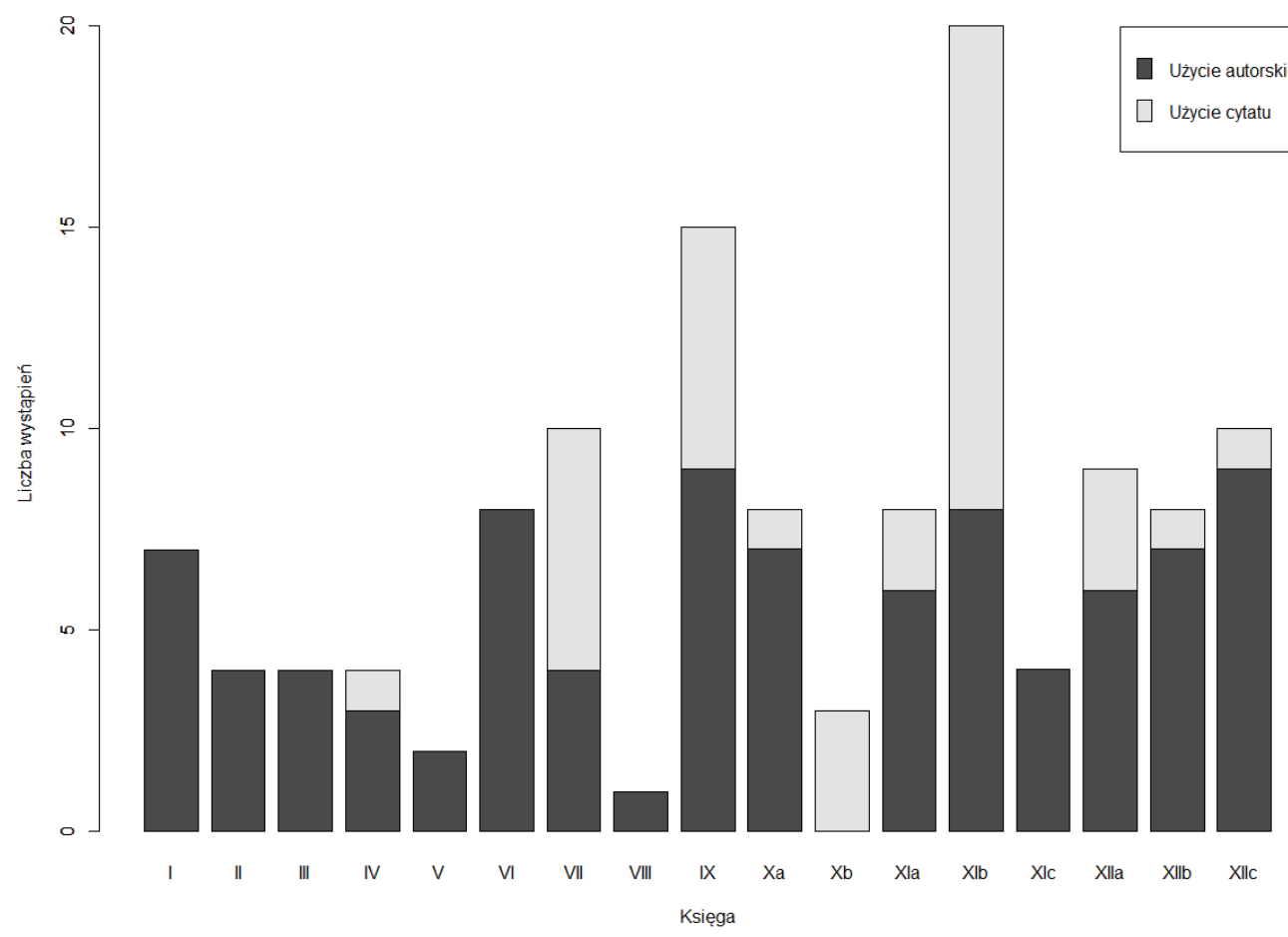

Wykres 1. Dystrybucja partykuł epistemicznych na przestrzeni poszczególnych ksiąg Roczników

Ze względu na naturę zjawiska należałoby założyć, że leksykalne wykładniki modalności epistemicznej będą znacznie częściej występować w partiach tekstu, które szczególnie wyraźnie odzwierciedlają osobiste poglądy autora. Największej ich liczby należałoby zatem spodziewać się $w$ księgach XI i XII, relacjonujących wydarzenia bliższe czasom Długosza. Z podsumowania wyników wypływa jednak inny wniosek - dystrybucja partykuł w obu częściach dzieła, „historycznej” i współczesnej Długoszowi, jest nieomal równa (63:61), z nieznaczną przewagą wystąpień interesujących nas partykuł w części pierwszej. Przewaga ta wyraźnie uwidocznia się dopiero podczas analizy samych tylko autorskich użyć partykuł epistemicznych (50:38). Warto mieć na uwadze to, że duża liczba cytatów we współczesnych partiach tekstu wynika z większej dostępności źródeł dokumentowych (NALEWAJEK, 2006: 43-44).

Wbrew przyjętemu założeniu Długosz wykazuje tendencję do stosowania badanych wykładników modalności epistemicznej w stosunku do wydarzeń przeszłych. Ich wykorzystanie może tutaj służyć uwiarygodnieniu przedstawianej historii i przekonaniu czytelnika do swoich racji, może też - przy tak dużej liczbie i rozbieżności źródeł historycznych (NowaKowsKı, 2012: 20-25) - stanowić dowód na wnikliwość i skrzętność dziejopisa, który nie jest bezmyślnym kompilatorem, a w obliczu tych czy innych wątpliwości wyraża swoje zdanie za pomocą odpowiednich środków leksykalnych (por. Rzepiela, 2016: 245-249). 


\section{Analiza syntaktyczna i pragmatyczna}

Zgodnie z przyjętymi założeniami partykuły epistemiczne mogą mieć różny zasięg oddziaływania (SGPP: 26) - wyrażenia, które zajmują otwierane przez partykułę miejsce i są przez nią komentowane, będą $w$ tym artykule określane jako punkty odniesienia partykuły. W tym miejscu należy zwrócić uwagę na wątpliwości i kontrowersje związane z odbiorem partykuł przez użytkownika języka - odbiór ten jest wysoce subiektywny i zależy od wielu czynników, między innymi położenia akcentu zdaniowego lub położenia partykuły $w$ linearnym szyku zdania (SGPP: 26, 28). Ponieważ $w$ tym przypadku badaniu podlega tekst pisany, $w$ dodatku $w$ języku historycznym, nie mamy możliwości analizy akcentu zdaniowego. Główny nacisk przy wskazywaniu punktu odniesienia będzie więc kładziony na linearny szyk i kontekst wypowiedzi, co powinno pozwolić zobiektywizować analizę i przynajmniej częściowo ułatwić wyznaczanie punktu odniesienia partykuły.

Taki punkt odniesienia mogą stanowić zarówno grupy werbalne (a dokładniej - człon nadrzędny grupy werbalnej) (a, b), jak i grupy nominalne (c) ${ }^{7}$. Trzeba jednak zaznaczyć, że w wypadku tych drugich punktu odniesienia nigdy nie stanowi ich człon nadrzędny (przynajmniej $w$ badanym korpusie) - partykuły mogą odnosić się jedynie do członu podrzędnego grupy nominalnej: najczęściej przymiotnika lub określnika, rzadziej liczebnika.

a) Si quis autem et sacras et gentiles historias velit percurrere, reperiet profecto in omni etate paucis bonis et virtuti deditis mirtos fuisse pessimos [...] (ANN. I 58) ${ }^{8}$;

b) De qua sane et suis virtutibus atque sanctis operibus tanta dici possunt [...] (ANN. VII 271)

c) Optimus plane ren, qui hostes suos non tam gladio quam mansuetudine et equitate vincebat, plus sacrificiis et oracione dimicans quam telis. (ANN. XIa 104) ${ }^{10}$.

Na podstawie dokładniejszych analiz można dojść do wniosku, że w wypadku partykuł epistemicznych w Rocznikach daje się zauważyć tendencję do ich współwystępowania z grupami werbalnymi (61\% przypadków). Zjawisko to w odniesieniu do grup nominalnych jest wyraźnie słabsze (32\%). Pozostałe 7\% przypadków to sytuacje, w których partykuła występuje w funkcji innego operatora (spójności lub dyskursu), a więc nie odnosi się do poszczególnych elementów zdania (na ten wynik składają się jedynie partykuły z gniazda pewnościowego).

Zarysowane tendencje $w$ obrębie poszczególnych gniazd rozkładają się jednak bardziej różnorodnie. O ile zgodnie z wcześniejszą obserwacją partykuły niewykluczające $w$ większym stopniu współwystępują z grupami werbalnymi (90\% przypadków) niż z grupami nominalnymi (10\%), o tyle $w$ grupie pewnościowej te proporcje są niemalże równe, chociaż z odwrotnymi proporcjami - do grup werbalnych odnosi się 42\% partykuł, a do grup no-

${ }^{7}$ Szerzej o przyjętym rozumieniu grup syntaktycznych por. KACzMARKowsKı, 1985: 92-93.

8 „Jeśli ktoś zechce przejrzeć dzieje święte czy też pogańskie, przekona się dowodnie, że w każdym wieku nieliczni dobrzy i oddani cnotom zmieszani byli z najgorszymi [...]" (Rocz. I 73).

9 „O niej, jej cnotach i świętych dziełach można naprawdę mówić tak dużo [...]” (Rocz. VII 345).

10 „Był to zaiste najlepszy król, który pokonywał swych wrogów nie tyle mieczem, ile łagodnością i sprawiedliwością, walcząc raczej ofiarami i modlitwą, niż strzałami" (Rocz. Xla 121). 
minalnych $-46 \%$. Ponadto $w$ tej grupie punkt odniesienia może zupełnie nie istnieć, gdyż partykuła może pełnić funkcję inną niż modalizującą (12\%). Przeprowadzone obserwacje zostały ujęte zbiorczo $w$ tabeli 2.

Tabela 2

Punkty odniesienia partykuł epistemicznych w Rocznikach

\begin{tabular}{|l|c|c|c|}
\hline \multirow{2}{*}{\begin{tabular}{c}
\multirow{2}{*}{$\begin{array}{c}\text { Rodzaj partykuły } \\
\text { a jej punkt odniesienia }\end{array}$} \\
\cline { 2 - 4 }
\end{tabular}} & $\begin{array}{c}\text { ogółem (124) } \\
{[\%]}\end{array}$ & $\begin{array}{c}\text { Piewykluczające (49) } \\
{[\%]}\end{array}$ & $\begin{array}{c}\text { pewnościowe (75) } \\
{[\%]}\end{array}$ \\
\hline Grupa nominalna & 31 & 10 & 46 \\
\hline Grupa werbalna & 62 & 90 & 42 \\
\hline $\begin{array}{l}\text { Brak (partykuła pełni } \\
\text { inną funkję) }\end{array}$ & 7 & - & 12 \\
\hline
\end{tabular}

W kontekście preferowanych punktów odniesienia warto przyjrzeć się danym dotyczącym poszczególnych partykuł (wykres 2):

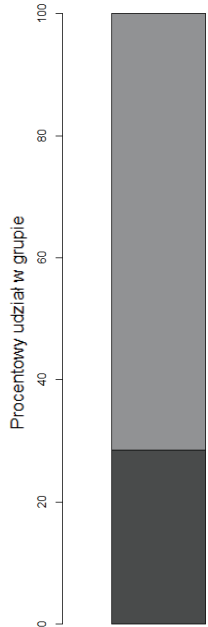

FORSAN

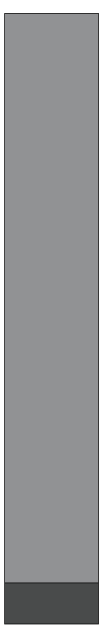

FORSITAN

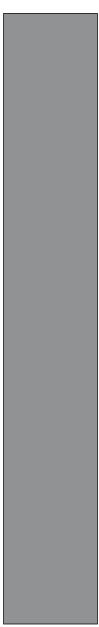

FORTASSE

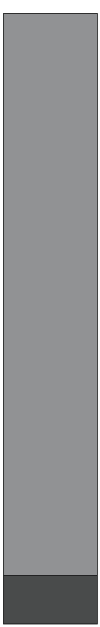

FORTE

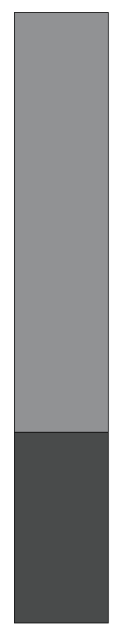

CERTE

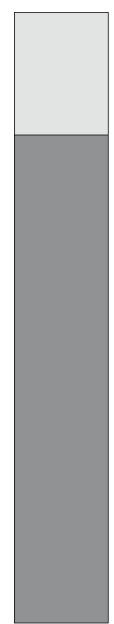

NEMPE

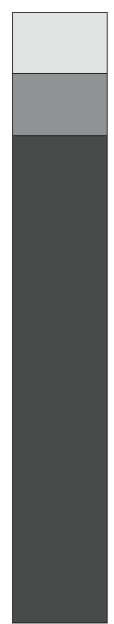

NIMIRUM

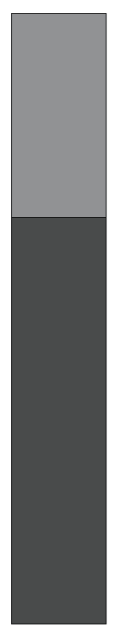

PLANE

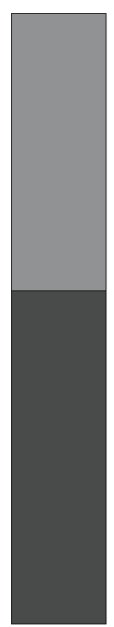

PROFECTO

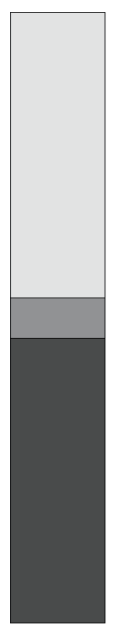

SANE

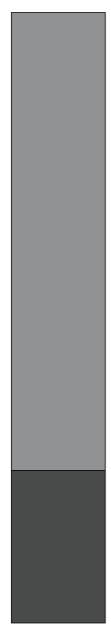

UTRUE

Grupa nominalna $\quad \square$ Grupa werbalna $\quad \square$ Brak

Wykres 2. Punkty odniesienia poszczególnych partykuł epistemicznych w Rocznikach

Większość badanych leksemów przyjmuje więcej niż jeden punkt odniesienia, dlatego można określić je mianem polireferencyjnych. Jedyną partykułą monoreferencyjną w Rocznikach jest fortasse, które występuje tylko odniesieniu do grup werbalnych. Trzeba jednak mieć na uwadze, że taki obraz tego leksemu w naszych badaniach może wynikać z niewielkiej liczby jego wystąpień $w$ korpusie.

W wypadku partykuł polireferencyjnych można wskazać na preferencje $w$ ich stosowaniu jako współwystępujących z określonymi elementami zdania. Na tej podstawie można wyróżnić w szczególności zbiór partykuł odnoszących się głównie do grup nominalnych (nimirum, plane, profecto) oraz tych odnoszących się głównie do grup werbalnych (forsan, forsitan, forte, certe, nempe, utique) - co ciekawe, do tej drugiej należą wszystkie pozostałe 
partykuły niewykluczające. Mimo takiego rozróżnienia widać jednak, że prawie każdy badany leksem ma odniesienie $w$ postaci grupy werbalnej - może to wskazywać na pewną prototypowość wzajemnych relacji czasowników i partykuł, co dodatkowo potwierdza związek tych drugich z klasą przysłówków (Rosén, 2009: 374-378; KleszczowA, 2015: 37-64). Wyjątkowo na tle przedstawionych zbiorów prezentuje się partykuła sane - często nie przyjmuje ona żadnego punktu odniesienia, pełni bowiem $w$ wypowiedzi funkcję innego operatora (spójności lub dyskursu).

Poprawne ustalenie punktów odniesienia i preferencji referencyjnych ma dla badań nad partykułami łacińskimi ogromne znaczenie. Po pierwsze, umożliwia ono potwierdzenie przyjętego założenia na temat ich klasy w ogóle - mogą się one odnosić do różnych klas gramatycznych. Po drugie, umożliwia uwypuklenie podobieństw i różnic między gniazdami niewykluczającym i pewnościowym oraz zwrócenie uwagi na ich cechy wewnętrzne. Po trzecie, ułatwia analizę linearnego szyku zdania, która może przynieść dodatkowe informacje o pragmatyce partykuł epistemicznych.

Zgodnie z ujęciem Grochowskiego partykuły epistemiczne występują w jukstapozycji wyrazu, do którego się odnoszą, nie mają jednak ściśle narzuconej pozycji w strukturze zdania. Ich szyk jest zmienny i zależny od innych elementów wypowiedzi. Warto również odnotować, że w języku mówionym nie muszą się one znajdować w jukstapozycji swojego punktu odniesienia, którym może być znajdujący się w dalszej części zdania wyraz akcentowany (SGPP: 26). Partykuły w języku łacińskim zdają się zachowywać identycznie, choć $w$ ich wypadku można wyróżnić jeszcze jedną cechę dystynktywną - bardzo rzadkie występowanie na końcu zdania (Rosén, 2009: 338-339).

Partykuły epistemiczne w Rocznikach znajdują się najczęściej na drugim miejscu w zdaniu (69\% przypadków), a znacznie rzadziej w jego dalszej części (21\% przypadków) lub w pozycji inicjalnej (10\%). Wyniki w poszczególnych gniazdach są do siebie zbliżone z wyraźnym wyjątkiem kwestii pierwszego miejsca w zdaniu - $w$ niewykluczającym na początku wypowiedzi występuje tylko 4\% partykuł (są to dwa wystąpienia leksemu forte), w pewnościowym z kolei jest to aż 15\% (są to leksemy: nempe - 2 razy, nimirum - 1 raz, profecto - $1 \mathrm{raz}$, sane - 7 razy). Zbiorczo zostało to przedstawione w tabeli 3 .

Tabela 3

Pozycja partykuł epistemicznych w linearnym szyku zdania w Rocznikach

\begin{tabular}{|l|c|c|c|}
\hline \multirow{2}{*}{$\begin{array}{c}\text { Rodzaj partykuły } \\
\text { a jej pozycja w zdaniu }\end{array}$} & \begin{tabular}{c}
$|c|$ \\
ogółem (124) \\
\cline { 2 - 4 }
\end{tabular} & $\begin{array}{c}\text { Partykuły } \\
\text { [\%] }\end{array}$ & $\begin{array}{c}\text { pewnościowe (75) } \\
{[\%]}\end{array}$ \\
\hline Pierusza & 10 & 71 & 15 \\
\hline Druga & 69 & 25 & 66 \\
\hline Dalsza & 21 & $49)$ & 19 \\
\hline
\end{tabular}

Istotna różnica $w$ częstotliwości występowania partykuły na początku zdania wynika z tego, że leksemy nempe, nimirum i sane występują w Rocznikach nie tylko w funkcji modalizującej. Funkcjonują one również jako partykułowe operatory spójności w wypadku nempe i nimirum oraz operatory dyskursu $w$ wypadku sane, i właśnie dlatego stoją $w$ pozycji inicjalnej. Służą do uściślenia treści wypowiedzi (d, e) lub rozpoczęcia nowej myśli (f): 
d) Quorum alterum, Bohemie regem pellere en Bohemia, alterum vero, nempe Polonie regem, suapte calvum amplius se decalvaturam [...] destinabat (ANN. XIIc 299) ${ }^{11}$;

e) Quorum quidam dicebant, quod hoc fuerat factum diabolica arte, nimirum cum predecessores eorum de Christo maxima miracula faciente "In Belzebub eiicit demonia" (Mathei nono capitulo) (ANN. VII 281) ${ }^{12}$;

f) Ut id ad curam sanus fuisse cognoscat, quod infirmus non poterat presentire. Sane postquam idem obstinatus spiritualem medicinam respuit [...] (ANN. VII 113) ${ }^{13}$.

Warto jednak spojrzeć na przytoczone powyżej cytaty przez pryzmat ustaleń na temat autorstwa poszczególnych wypowiedzi w Rocznikach. Okazuje się bowiem, że (e) zostało przez Długosza zaczerpnięte z Fortalitium fidei Alphonse’a ze Spiny (BorkowskA, 1983: 186 [przyp. 11]), a zatem użyta $w$ ten sposób partykuła nimirum nie może być uważana za przejaw idiostylu polskiego autora. Podobnie jest z (f) oraz sześcioma innymi przykładami z sane $w$ pozycji inicjalnej $w$ zdaniu - wszystkie one pochodzą z cytowanych listów papieskich, a więc ich użycie $w$ tej pozycji nie może być uznane za zabieg właściwy stylowi Długosza. Jedno z dwóch nempe stojących na początku zdania funkcjonuje jako partykułowy operator spójności (d) i chociaż należy do wypowiedzi autorskich, to jego unikatowość połączona $z$ doborem rzadkiego dla historyka słownictwa w cytowanym fragmencie pozwala domniemywać, że może pochodzić z wciąż nieznanego źródła (przypuszczalnie niemieckiego, por. Dábrowskı, 1965: 298). Tak więc także i w tym przypadku trudno mówić o cechach charakterystycznych dla idiostylu autora.

Przeprowadzone analizy pokazują, że znakomita większość partykuł $w$ funkcji stricte modalizującej występuje $w$ dziele Długosza na drugim miejscu $w$ zdaniu. Jest to łatwe do wytłumaczenia w wypadku odniesienia do grup nominalnych (25\%). Standardowym, neutralnym szykiem $w$ zdaniu łacińskim jest kolejność podmiot-dopełnienie-orzeczenie (SOV), w związku z czym grupy nominalne, do których odnoszą się partykuły, będą bliżej pozycji inicjalnej w zdaniu (Devine, Stephens, 2006: 79).

Nieoczywista jest jednak tendencja do współwystępowania partykuł - stojących na drugim miejscu w zdaniu - z grupą werbalną. Stanowi ona, jak wykazano, punkt odniesienia większości badanych leksemów (75\% przypadków). Wystąpienia te można jednak podzielić na dwie podgrupy - partykuły z punktem odniesienia w jukstapozycji i partykuły z oddalonym punktem odniesienia. Jukstaponowane grupy werbalne stanowią mniejszą część odniesień partykuł epistemicznych w Rocznikach (14\%) wśród leksemów należących do gniazda zarówno niewykluczającego, jak i pewnościowego. Znacznie częściej grupa werbalna jest oddalona od partykuły (61\%). Zbiorczo przedstawia to tabela 4.

11 „Jednego z nich, króla czeskiego, postanowił wypędzić z Czech, drugiego, mianowicie polskiego, już zaiste łysego, jeszcze bardziej pozbawić włosów [...]” (Rocz. XIIc 314).

12 „Jedni z nich mówili, że są to sztuczki diabelskie, bo ich przodkowie to właśnie mówili o Chrystusie, kiedy dokonywał największych cudów: „W imię Belzebuba wyrzuca czarty” (w dziewiątym rozdziale Mateusza)" (Rocz. VII 359).

13 „Aby odzyskawszy zdrowie poznał, że przedmiotem troski było to, czego jako chory nie mógł zrozumieć. Zaiste, skoro on uparcie odrzuca duchowe lekarstwo [...]” (Rocz. VII 141). 
Tabela 4

Preferowany punkt odniesienia partykuły epistemicznej stojącej na drugiej pozycji $w$ linearnym szyku zdania w Rocznikach

\begin{tabular}{|l|c|c|c|}
\hline \multirow{2}{*}{$\begin{array}{c}\text { Rodzaj partykuły } \\
\text { a jej punkt odniesienia, } \\
\text { gdy stoi ona na drugiej pozycji w zdaniu }\end{array}$} & $\begin{array}{c}\text { Półem (85) } \\
{[\%]}\end{array}$ & $\begin{array}{c}\text { niewykluczające (36) } \\
{[\%]}\end{array}$ & $\begin{array}{c}\text { pewnościowe } \\
\text { [\%] }\end{array}$ \\
\cline { 2 - 4 } & $149)$ & 14 \\
\hline $\begin{array}{l}\text { Grupa werbalna stanowiąca jukstapono- } \\
\text { wany punkt odniesienia }\end{array}$ & 14 & 85 & 40 \\
\hline $\begin{array}{l}\text { Grupa werbalna stanowiąca oddalony } \\
\text { punkt odniesienia }\end{array}$ & 61 & - & 46 \\
\hline Grupa nominalna & 25 & -15 \\
\hline
\end{tabular}

Zjawisko to można prawdopodobnie wytłumaczyć regułami szyku łacińskiego. Trzeba jednak zauważyć, że przynosi ono ważną obserwację na temat partykuł epistemicznych ich położenie nie jest zależne od pozycji własnego punktu odniesienia, ponieważ zazwyczaj znajdują się one na ustalonym domyślnie drugim miejscu $w$ linearnym szyku zdania. W podobny sposób funkcjonuje $w$ języku łacińskim wiele innych partykuł, między innymi te o charakterze fokalnym: vero 'zaś, zaiste', quidem 'wprawdzie, zapewne', quoque 'również'. Ze względu na obligatoryjną drugą pozycję $w$ zdaniu są one określane mianem postpositive particles (partykuły postpozycyjne) (SPEVAK, 2010: 284). Warto przypomnieć, że ze względu na spory potencjał modalizujący Rosén umieszczała te właśnie leksemy $w$ grupie partykułowych operatorów modalnych (Rosén, 2009: 350-351). Na tej podstawie można więc wnioskować o częściowo ustalonej pozycji partykuł epistemicznych $w$ linearnym szyku zdania.

\section{Wnioski}

Obserwacje dotyczące funkcji i zakresu użycia partykuł epistemicznych w Rocznikach Jana Długosza pozwalają na sformułowanie następujących wniosków dotyczących ich cech:

1) są one polireferencyjne - współwystępują zarówno z grupami werbalnymi (wykazują do tego najsilniejszą preferencję), jak i z grupami nominalnymi;

2) w niektórych wypadkach pełnią funkcję inną niż modalizująca;

3) zazwyczaj znajdują się na drugiej pozycji w linearnym szyku zdania.

Analiza pozwoliła również wykazać współistnienie homonimicznych $w$ stosunku do partykuł przysłówków - użycie niektórych z nich (np. certe) nie jest jednak dla idiostylu Długosza swoiste, ponieważ $w$ wypowiedziach autorskich posługuje się on jedynie partykułowym wariantem leksemu.

W badaniach świadomie pomijałem niektóre aspekty odnoszące się do partykuł epistemicznych w Rocznikach, między innymi kwestię ich zależności gramatycznej od czasów i trybów czasownika (czy partykuła wpływa na formę orzeczenia, z którym współwystępuje) oraz zagadnienie kontekstu występowania partykuły epistemicznej w wypowiedzi (czy partykuły pojawiają się częściej w odniesieniu do określonych tematów i czy istnieje ich zależność od konkretnej postaci lub treści dzieła). Chociaż takie obserwacje mieszczą 
się w obrębie badań pragmatycznych i mogłyby dostarczyć nowych informacji badaczom tekstu Długosza, nie znajdują się one w tej chwili w obszarze moich zainteresowań i celów powstającej rozprawy doktorskiej.

Na koniec trzeba jeszcze odpowiedzieć na pytanie: Czy użycie partykuł epistemicznych w Rocznikach, czyli tekście średniowiecznym, odbiega w jakiś sposób od normy językowej utrwalonej w łacinie klasycznej? Z przedstawionej analizy wynika, że nie - Długosz wykorzystuje te partykuły zgodnie z regułami gramatycznymi i pragmatycznymi języka łacińskiego. Zdaje się to tylko potwierdzać wysoki poziom klasycznego wykształcenia polskiego kronikarza. Analizowany materiał, chociaż należy do korpusu średniowiecznego, wykazuje wyraźną bliskość z tekstami korpusu autorów antycznych, a więc źródłami literatury i myśli humanistycznej. To z kolei stanowi jeszcze jeden argument $w$ trwającej od wielu lat dyskusji o charakterze twórczości Długosza, przybliżający badaczy do zaliczenia go w poczet polskich protohumanistów.

\section{Słowniki}

SGPP - Grochowskı M., KıSıEl A., ŻAвowskA M., 2014: Słownik gniazdowy partykut polskich. Polska Akademia Umiejętności. Kraków.

\section{Źródła}

Annales [Ann.] - Dąbrowskı J. i in., wyd., 1964-2005: Ioannis Dlugossi Annales seu Cronicae incliti Regni Poloniae. Libri I-XIIc. Państwowe Wydawnictwo Naukowe. Warszawa.

Rocznıkı [Rocz.] - Mrukówna J. i in., tłum., 1961-2006: Jana Długosza Roczniki czyli Kroniki sławnego Królestwa Polskiego. Księgi I-XIIc. Państwowe Wydawnictwo Naukowe. Warszawa.

\section{Literatura}

Allen J., Greenough J., 2006: New Latin Grammar for Schools and Colleges. Dover Publications, Inc. Mineola, NY.

Borkowska U., 1983: Treści ideowe w dziełach Jana Długosza. Kościół i świat poza Kościołem. Redakcja Wydawnictw KUL. Lublin.

Bortolussi B., 2000: La grammaire du latin. Hatier. Paris.

Dąвrowskı J. i in., 1965: Rozbiór krytyczny „Annalium Poloniae” Jana Długosza z lat 1445-1480. T. 2. Zakład Narodowy im. Ossolińskich, Wydawnictwo Polskiej Akademii Nauk. Wrocław.

Dinkova-Bruun G., 2011: Medieval Latin. In: Clackson J., ed.: A Companion to the Latin Language. Wiley-Blackwell. Chichester-Malden, s. 284-302.

Devine A.M., Stephens L.D., 2006: Structured Meaning and Information: Structured Meaning and Information. Oxford University Press. New York.

GAWLAS S., 1983: Świadomość narodowa Jana Długosza. „Studia Źródłoznawcze”, XXVII, s. 3-66. GrzegorczyKowa R., 2010: Wprowadzenie do semantyki językoznawczej. Wydawnictwo Naukowe PWN. Warszawa. 
Hoffman J., Szantyr A., 1972: Lateinische Syntar und Stilistik. C.H. Beck. München.

Kaczmarkowskı M., 1985: Nominalne grupy syntaktyczne łaciny okresu klasycznego. Redakcja Wydawnictw KUL. Lublin.

Kleszczowa K., 2015: U źródeł polskich partykuł. Wydawnictwo Uniwersytetu Śląskiego. Katowice. Kroon C., 1995: Discourse Particles in Latin. A Study of "nam”, „enim”, „autem”, "vero" and „at”. J.C. Gieben. Amsterdam.

Kroon C., 2011: Latin Particles and the Grammar of Discourse. In: Clackson J., ed.: A Companion to the Latin Language. Wiley-Blackwell. Chichester-Malden, s. 176-195.

Magni E., 2010: Mood and Modality. In: BAldi Ph., Cuzzolini P., eds.: New Perspectives on Historical Latin Syntan, II: Constituent Syntan: Adverbial Phrases, Adverbs, Mood, Tense. Mouton de Gruyter. Berlin-New York, s. 193-275.

Nalewajek A., 2006: Dokument w „Rocznikach” Jana Długosza. Towarzystwo Naukowe Katolickiego Uniwersytetu Lubelskiego Jana Pawła II. Lublin.

Nowakowskı T., 2012: Źródła Jana Długosza do dziejów Mazowsza w XI-XIV wieku: w poszukiwaniu rocznika płockiego. Wydawnictwo Uniwersytetu Kazimierza Wielkiego. Bydgoszcz.

Pinkster H., 2015: Orford Latin Syntar. Vol. 1: The Simple Clause. Orford University Press. Orford. Rajfura H., 2018: Nowe badania nad życiem i twórczościa Jana Długosza. Osiągnięcia i potrzeby. „Studia Źródłoznawcze”, LVI, s. 193-199.

Ramat P., Ricca D., 1998: Sentence Adverbs in the Languages of Europe. In: AuwERA J. V. D., BAoILL, D.P.Ó., eds.: Adverbial Constructions in the Languages of Europe. Mouton de Gruyter. Berlin, s. $187-275$.

Rosén H., 2009: Coherence, Sentence Modification, and Sentence-part Modification: The Contributio of Particles. In: Baldi Ph., Cuzzolini P., eds.: New Perspectives on Historical Latin Syntar, I: Syntar of the Sentence. Moutin de Gruyter. Berlin-Boston, s. 317-441.

Rzepiela M., 2016: Rola frazeologii w narracji „Kroniki” Jana Długosza. W: KorczaK L., KowalSkı M.D., Wécowskı P., red.: Jan Długosz (1415-1480). Życie i dzieła. Towarzystwo Wydawnicze „Historia Iagellonica". Kraków, s. 237-250.

Schrickx J., 2011: Lateinische Modalpartikeln. „Nempe”, „quippe”, „scilicet”, „videlicet” und "nimirum”. Brill. Leiden-Boston.

Spevak O., 2010: Constituent Order in Classical Latin Prose. John Benjamins. Amsterdam-Philadelphia. Weyssenhoff-Brożkowa K., 1998: Wpływ polszczyzny na łacinę średniowieczna $w$ Polsce. PAN, IJP. Kraków.

WikARJAK J., 2019 [1978]: Gramatyka opisowa języka łacińskiego. Wydawnictwo Naukowe PWN. Warszawa.

Wolanin H., 2012: Gramatyka opisowa klasycznej łaciny w ujęciu strukturalnym. Księgarnia Akademicka. Kraków. 